ICTD Working Paper 132

\section{Glimpses of Fiscal States in Sub-Saharan Africa}

Mick Moore

November 2021 
Glimpses of Fiscal States in Sub-Saharan Africa

Mick Moore

ICTD Working Paper 132

First published by UNU-WIDER in October 2021

CUNU-WIDER 2021

ISBN: [978-1-78118-871-2]

DOI: 10.19088/ICTD.2021.022

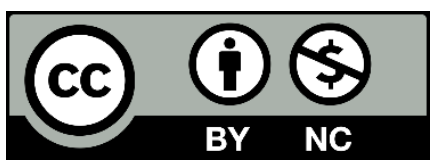

This study is reproduced here with full acknowledgement of UNU-WIDER, Helsinki. The study was originally commissioned under the UNU-WIDER project Fiscal states-the origins and developmental implications and published as WIDER Working Paper $2021 / 151$

This is an Open Access paper distributed under the terms of the Creative Commons Attribution Non Commercial 4.0 International license, which permits downloading and sharing provided the original authors and source are credited - but the work is not used for commercial purposes. http://creativecommons.org/licenses/by-nc/4.0/legalcode

Available from:

The International Centre for Tax and Development at the Institute of Development Studies, Brighton BN1 9RE, UK

Tel: +44 (0) 1273606261

Email: info@ictd.ac

Web: www.ictd.ac/publication

IDS is a charitable company limited by guarantee and registered in England

Charity Registration Number 306371

Charitable Company Number 877338 


\title{
Glimpses of Fiscal States in Sub-Saharan Africa
}

\author{
Mick Moore
}

\section{Summary}

There is a widespread perception that taxing in sub-Saharan Africa has been and remains fraught with problems or government failure. This is not generally true. For more than a century, colonial administrations and independent states have steadily developed the capacity to routinely collect more substantial revenues than one might expect in a low-income region. The two main historical dimensions of this collection capacity were (a) powerful, centralized bureaucracies focused on achieving revenue collection targets and (b) large, taxable international trade sectors. In recent decades, those centralized bureaucracies have to some extent been reformed such that in structure and procedure they resemble more closely tax administrations in OECD countries. More strikingly, nearly all states have adopted VAT and found it to be a very powerful revenue collection instrument. However, the tax share of GDP has been broadly constant for several decades, and it will be hard to increase it. It is difficult for African governments to effectively tax transnational corporations, especially in the mining and energy sectors, which are of growing importance. Tax administrations continue to approach richer Africans with a light touch, and to exaggerate the potential for taxing small-scale ('informal') enterprises. The revenue operations of sub-national governments are often opaque. Ordinary people often pay large sums in 'informal taxes' that are generally regressive in impact. And the standard direction of travel in the reform of tax policy and administration is not appropriate to those large areas, especially in the Sahel, that are afflicted by internal and cross-border armed conflicts.

Keywords: tax, revenue, sub-Saharan Africa, history, tax reform, tax administration, customs.

Mick Moore is a Senior Fellow at the International Centre for Tax and Development and a Professorial Fellow at the Institute of Development Studies. 


\section{Contents}

Summary 3

Acknowledgements $\quad 5$

Introduction 6

$1 \quad$ Proficient tax collectors $\quad 8$

$2 \quad$ New historical revenue data 9

3 The historical trajectory: the colonial era 10

$4 \quad$ The historical trajectory: independence and after 13

$\begin{array}{lll}5 & \text { Revenue reform } & 15\end{array}$

$\begin{array}{lll}6 & \text { Extractives problems } & 18\end{array}$

$\begin{array}{lll}7 & \text { Glimpses of fiscal states } & 20\end{array}$

$\begin{array}{ll}\text { References } & 24\end{array}$

Tables

Table 1 Average national trade ratio (ratio of imports and exports to GDP) For 3 regions, by decade, 1960-2019 12

Table $2 \quad$ Natural resource rents as a percentage of GDP by decade and source, SSA

Table 3 Total natural resource rents as a percentage of GDP, by world region 1971-2018 18

Table 4 Extent of government capture of natural resource rents, 2017-21 19

Table 5 Extent of government capture of natural resource rents, 2014-18 19 


\section{Acknowledgements}

I am grateful to Willie Khoo for extensive help in identifying and organizing much of the data used here; and to the following people for very helpful comments on an earlier version: Per Andersson, Odd-Helge Fjeldstad, Mette Kjaer, Oliver Morrissey, Antonio Savoia, Kunal Sen, and Matthias vom Hau. 


\section{Introduction}

If you play the word association game with tax and African states, what other words come to mind? For many people interested in development policy or Africa, the answer will likely include: difficult, challenging, inefficient, and inexperienced. There is a widespread perception that in sub-Saharan Africa (SSA) taxing is a new enterprise and/or has been and remains fraught with problems or government failure. Those perceptions are bolstered by a range of more specific narratives: that African governments cannot raise enough tax revenue to finance essential functions, and continue to depend heavily on foreign aid; that the coercive nature of direct colonial taxation made it very difficult for later governments to collect taxes; that Africans today are sceptical and hostile towards official tax collectors, and widely view them as corrupt; and that many Africans identify so strongly with particular ethnic, religious, or regional groups that they feel no obligation to pay taxes to central government.

There is some truth in all these narratives. But the overall implication is wrong. Taxing is not an unfamiliar enterprise. Sub-Saharan African states do not on average tax particularly poorly. In fact, today they are quite proficient tax collectors. At least until the Covid pandemic pushed them deep into debt, a growing number of them were becoming fiscal states, i.e. they possessed sufficiently reliable tax bases-and thus debt repayment capacity-to borrow, at commercial rates, on international financial markets (African Development Bank 2021: 49-50). After a couple of decades of economic stagnation or decline in the 1970s to 1990s, some African economies began to grow relatively fast. Government revenue collections increased accordingly. They began to exceed aid inflows around 1995, and today are the dominant source of government income. While aid remains significant, aid dependence is now confined to a small number of especially troubled states (Moore et al. 2018: 29-30).

The aid dependence that many people associate with SSA had neither a long nor a deep history. The average government in the region received more money from aid donors than it raised in taxes only for about a decade, from the mid-1980s to the mid-1990s (Moore et al. 2018: 29-30). Long before that, colonial and independent governments funded themselves almost entirely from internal revenue sources. With significant wobbles only between the mid-1970s and the mid-1990s, governments in SSA otherwise steadily increased the proportion of GDP that they captured as revenue from 1900 almost until today. ${ }^{1}$ Although they rarely attained the status of fiscal states, in that they generally could not borrow long term at commercial rates of interest in international financial markets, they were tax states according to Schumpeter's definition (Schumpeter 1918/1991): they financed themselves mainly from broad general taxation, and not principally from the earnings of state-owned assets like land, industry, mines, post offices, and railways, or from state trading monopolies in products like salt or alcohol.

Contemporary sub-Saharan African governments on average score better than their counterparts in South Asia and Latin America and the Caribbean in quantitative performance measures relating to (a) the amount of revenue raised (relative to potential revenue) and (b)

I note in passing the irony that, while there is a large academic literature analysing the recurrent failures of many African states to perform the basic governance task of effectively controlling territory, populations, and borders (e.g. Bayart 1993; Bayart et al. 1999; Chabal and Daloz 1999; Englebert 2000), their relative success in the equally basic function of raising revenue has gone largely unnoticed by Africanist scholars. Similarly, in the literature and debates about government revenue in contemporary SSA, there is near silence on an issue that features regularly in the standard histories of fiscal states: the extent to which revenue-collecting activities are unified and coherent, or dispersed and competitive (Yun Casalilla and O'Brien 2012). 
the effectiveness of national tax administrations (Section 1). However, if we examine the functioning of African revenue systems from the perspectives of taxpayers or tax administration specialists, it seems less impressive. Revenue burdens are often distributed very unfairly; extortion and corruption in assessment and collection are not rare; there is little transparency; and procedures for registration, assessment, and collection are often unnecessarily inconvenient for taxpayers (Section 5).

The first purpose of this paper is to explain the tension between these two somewhat contradictory sets of observations: modest success when judged in terms of aggregate comparative performance measures, but very visible, concrete problems in organizational processes, including in interactions with taxpayers. There are two main steps in the explanation.

First, African national tax administrations have been able, over long periods of time, to raise significant revenues from what are, from an organizational and political perspective, two distinctly different types of revenue:

(a) The first is easy taxes. ${ }^{2}$ This is revenue from sources that can be identified relatively simply and accurately by tax administrations, and thus costs little to collect and does not provoke strong taxpayer resistance at the points of assessment or collection. In varying ways over the period of 120 years for which we have data, international trade has been the major source of easy taxes in SSA.

(b) The second is challenging-but-enforceable taxes. These have three characteristics: taxpayer identification and revenue collection require considerable organizational effort on the part of tax administrations; they are intrinsically likely to generate high levels of taxpayer resentment and resistance; but they nevertheless can be collected because taxpayers are most of the time politically too weak to resist a determined organizational effort. The classic examples are colonial-era 'head and hut' taxes (Section 3). There are, however, elements of these challenging-but-enforceable taxes in more recent and contemporary African revenue systems (Moore 2020).

Second, and consequently, revenue systems in SSA have not been significantly shaped by extended, robust confrontation and political negotiation between governments and tax administrations on the one side and, on the other, organizations representing the collective interests of major taxpayer groups. ${ }^{3}$ Governments have been able to raise significant revenues without taking the political risk of challenging powerful taxpayer interest groups. Large taxpayers typically engage with government over tax issues on an individual rather than a collective basis.

The second purpose of the paper is to use these insights into the history of taxation in SSA to make a judgement about the scope for contemporary governments to increase revenues - and especially to increase the proportion of GDP taken in taxes-to enable them, for example, to better deal with the consequences of the Covid pandemic, or otherwise promote more equitable human development. The judgement is presented in more detail in Section 7. The main conclusion is that, although sub-Saharan African states have long been better revenue collectors than they are often given credit for, they seem currently to have reached a performance plateau. Despite many positive signs, the ratio of tax to GDP seems

'Easy' and 'challenging-but-enforceable' taxes are my terms. The current conventional distinction between direct and indirect taxes has its origins in abstract economic thinking. It does not coherently capture important differences in the political and organizational context in which taxes are collected. The meaning has also changed over time (Keen and Slemrod 2021: 117)

3 The most obvious exception to this statement is South Africa. For the historical context on that case, see Lieberman (2003). 
not to have been increasing in recent decades. There is no obvious reason to expect that to change. Meanwhile, changes in economic structures are not making revenue collection consistently easier.

\section{Proficient tax collectors}

The most basic and common measure of national revenue collection performance- the 'tax take'-is revenue collected annually as a proportion of GDP. ${ }^{4}$ According to this measure, SSA performs well compared with the two other relatively homogeneous and lower-income world regions: South Asia and Latin America and the Caribbean. ${ }^{5}$ All three regions are poor, but not equally so. SSA is classified by the World Bank as a Low-Income region, South Asia as Lower Middle-Income, and Latin America and the Caribbean as Upper Middle-Income. For the period 2011-15, the regional average figures for tax collection as a proportion of GDP are 21 per cent for SSA, 16 per cent for South Asia, and 22 per cent Latin America and the Caribbean (Moore et al. 2018: 32). The normal expectation is that the ratio of revenue collection to GDP will be higher in richer countries. Yet the collection figure for SSA is higher than for richer South Asia, and only slightly less than much-richer Latin America and the Caribbean. On this basic measure of quantitative collection performance, SSA seems to perform well.

We can strengthen that finding using a more refined analytic technique. It is not only income per head that is in a statistical sense correlated with the size of the national tax take. Repeated econometric analysis using cross-section and time series data relating to large samples of countries tells us that there are other characteristics of national economies that are consistently associated with the size of the tax take. For reasons that are not hard to understand, countries that have high ratios of international trade (imports and exports) to GDP and larger non-agricultural or urban sectors also score higher in terms of tax collection (Chang et al. 2020: 7). On the basis of these consistent patterns, statisticians are able to calculate the tax effort for any country. This is defined as the difference between the amount of revenue actually collected and the amount that a country might be predicted to collect in the light of its economic structure (income per head, the ratio of international trade to GDP, the size of the non-agricultural sector, etc.). In practice, it is difficult to calculate tax effort, above all because a great deal of trustworthy data is required. Those reliable estimates that we have clearly indicate that tax effort is higher in SSA than in South Asia or Latin America and the Caribbean (Moore et al. 2018: 31-32). This confirms that governments in contemporary SSA tax more heavily than those in the comparator regions.

We reach a similar conclusion if we compare the revenue collection performance of contemporary sub-Saharan African governments with that of the governments of the nowrich countries at the point in history when their citizens enjoyed levels of GDP per capita similar to those in SSA today. For example, when citizens of Denmark, France, Italy, and Japan had an average per capita income of about $\$ 1,000$ (GK\$, 1990 prices), their governments on average collected about 8 per cent of GDP in taxes. In those contemporary

This is an imperfect measure of the tax take, principally because of the unreliability of many estimates of GDP, especially in Africa (Jerven 2013; Prichard 2016). The errors are, however, probably largely random. It is highly unlikely that they would affect the intra-regional comparisons presented in the main text. Note also that in formal revenue accounts, total government revenue is divided between tax revenue and non-tax revenue. The conceptual distinction is, however, fuzzy, and actual accounting practices vary from country to country. Arrangements to collect non-tax revenue are similar to those used to collect tax revenue. In referring to tax collection or revenue collection in this paper, I mean total government revenue collection unless otherwise specified.

5 The rest of Asia is very diverse and generally much richer than Africa. In the Middle East and North Africa, oil and gas extraction dominates as a source of government revenue. 
sub-Saharan African countries where average incomes are also around $\$ 1,000$ (GK\$, 1990 prices), governments collect 12-13 per cent of GDP in revenue. ${ }^{6}$

\section{New historical revenue data}

When did governments in SSA emerge as relatively successful tax collectors? It is only recently, and thanks to the efforts of researchers attached to the African Economic History Network based at Lund University, that we have enough information to address this question. We now have a dataset on government revenues for SSA for the period since 1900 , i.e. broadly the moment when colonial occupation of most of the region was completed (Albers et al. 2020). ${ }^{7}$ Assembling data on the value of annual revenue collections for each government for over a century is laborious, but not conceptually too challenging. ${ }^{8}$ The more testing task is to find a way of representing historical government revenue collections as a ratio of some other meaningful measure of national economic activity. The standard contemporary measure — revenue as a percentage of GDP_cannot be used, because even partly reliable GDP figures for African countries go back at best a few decades (Jerven 2013). The Lund researchers solved this problem by calculating, for each country and each year, the proportion of the total annual number of labour days potentially available from the adult population that could be purchased with the revenue collected by government. In other words, they tell us how many labour days per year the government could purchase from the average adult citizen, paid at the average urban unskilled wage rate, if it were to use all its revenue solely for this purpose. This is a real measure of the value of government revenues, albeit not the only one that might in principle be used.

The Lund dataset is still a work in progress. But its limitations need not concern us here, because we are interested only in broad trajectories. On average, government revenues increased relatively steadily throughout the period, such that, in real terms, they are 11 times as large today as in 1900 (Albers et al. 2020: 5). In the first decade of the 20th century, the average government in SSA raised enough revenue to employ every adult citizen for about 8 days a year. By 1960, it was about 20 days. In the most recent decade, it has been close to 100 days. The only significant exception to the overall trend of steadily increasing average revenues is that for a period of around two decades, from the mid-1970s to the mid-1990s, average national revenues almost plateaued (Section 4).

\footnotetext{
$6 \quad$ Cathal Long and Mark Miller did the original calculations, showing that the tax-to-GDP ratios of developing countries today 'are not that different from those of today's higher income countries when they were at a similar stage of development' (Long and Miller 2017: 7 and figure 8). They kindly provided access to their original data, which enabled us to demonstrate that, among developing countries, those in SSA are especially likely to collect more revenue today than did now-rich countries at similar income levels.

7 Because the focus of this paper is on macro historical revenue trends, I do not directly cite-and therefore perhaps appear to under-appreciate - a great deal of stimulating research on a wide range of issues relating to state revenues in colonial Africa, especially much of the work of Ewout Frankema.

8 Except that, in the early colonial period, some 'revenues' were collected in the form of forced labour (Section 2).
} 


\section{The historical trajectory: the colonial era}

Three major revenue categories, of approximately equal importance, provided the bulk of colonial state incomes in the earlier half of the 20th century: direct ${ }^{9}$ taxes on African individuals and households ('head and hut taxes'), trade taxes, and non-tax revenues. The academic and historical literature on Africa tends, understandably, to focus heavily on the first. ${ }^{10}$ Head and hut taxes were generally regressive in impact and collected oppressively, sometimes with the application of considerable force. They were occasionally associated with armed resistance to early colonial rule, which included the iconic 1898 Hut Tax War in Sierra Leone. It is easier to understand the other components of colonial revenue systems if we first appreciate the history of head and hut taxes. ${ }^{11}$

In the late 19th and early 20th centuries-and excepting the brief competitive period labelled the 'scramble for Africa'-European governments had limited enthusiasm either for formally extending their African territorial claims or for actually administering the territories formally under their control. Proponents and local practitioners of colonial expansion learned that they could not expect the administration of newly acquired territories to be subsidized from London, Paris, or Lisbon. Neither were there pre-existing large scale revenue systems that could be taken over. Early colonial administrations were consequently very revenueconstrained, thin in terms of staff numbers, and heavily dependent on local intermediaries for actual revenue collection-and indeed for the performance of most administrative functions. Lacking immediate revenue alternatives, early colonial administrations clamped down on the population, house by house and adult male by adult male, extracting forced labour as well as cash. ${ }^{12}$

This revenue collection activity was meshed in contradictions. Population densities in Africa were generally very low. People were mobile and tied more to political networks than to specific pieces of land. Much cultivation was impermanent, and for auto-consumption. From the European perspective, land rights appeared complex and continuously negotiable. They were neither written nor mapped. From the perspective of large-scale bureaucratic political systems, it is very hard to tax this type of economy effectively or efficiently. Attempts to track and tax scattered, mobile subsistence cultivators almost inevitably result in a high ratio of collection costs to collections, especially as the collectors exercise wide discretion in their interactions with taxpayers. That in turn implies coercion, corruption, taxpayer resentment and the possibility of revolt. No government that had the choice would want to depend heavily on this revenue source. But early colonial administrations did not have a great deal of choice. At their peak, around 1920, these direct taxes levied on ordinary Africans accounted for around 40 per cent of total revenue collected by governments in SSA (Albers et al. 2020: 5). This represents only a few percentage points of GDP, but nevertheless is

In using the word 'direct', I am bypassing a substantial literature on the extent to which the agents who collected these taxes should be considered part of the state apparatus or of the machinery of 'indirect rule'. That question in turn connects to a range of other debates among historians: the extent to which the authority of the 'chiefs' who were the local agents of indirect rule derived purely from their appointment by the colonial state or had a pre-existing local basis; shifts over time in the fuzzy boundary between direct and indirect rule; and the stereotype of French colonial preference for direct rule over the British predilection for indirect rule. These debates are not directly relevant to this paper. (Hopkins 2009). Accordingly, taxation has been of interest to Africanist historians and social scientists more from the perspective of its impact on ordinary Africans than as a dimension of public finance or national political economy.

11 See especially Frankema and van Waijenburg (2014); Herbst (2000: chapter 1); and Young (1994: chapter 4).

12 The routine running costs of colonial administrations were unusually high relative to the incomes of the populations over which they ruled. In essence, near-subsistence cultivators were obliged, directly or indirectly, to finance the salaries of highly paid British and French administrators. That inequity generally persisted beyond independence. 
quite an achievement in purely quantitative terms. The primary collection mechanism was force:

The key to colonial state survival was the transformation of the able-bodied African adult male [...] into a state revenue flow. Such a transaction required large amounts of force. The many brutalities associated with the early colonial years, the arsenal of arbitrary legislation with which all colonial regimes equipped their field officers [...] and the command nature of the colonial state all trace their origin to this basic fact (Young 1994: 105).

This willingness to create the administrative capacity to impose harsh taxation on poor, dispersed populations was particularly evident in those parts of Eastern and Southern Africa that Thandika Mkandawire (2010) characterized as 'Africa of the labour reserves'. ${ }^{13}$ Here, white-owned agricultural, plantation, and mining enterprises needed a great deal of African labour. Colonial taxation and other policies were designed to encourage or oblige African males to meet that need. The outcome was high levels of revenue and of state capacity generally. Tax effort, calculated as explained in Section 1, was unusually high in the labour reserve economies, as was the proportion of revenue raised through direct income taxes levied on individuals and businesses. That pattern is still evident today. ${ }^{14}$ This part of Africa in particular has become a semi-permanent, partial exception to the rule that governments of low-income countries find it difficult to raise revenue through direct income taxes.

Direct head and hut taxes served non-revenue purposes. They helped to increase the flow of manual labour to European-owned enterprises, and provided means-formal or informal-of remunerating the local agents of colonial rule who were responsible for collecting them. However, for the reasons explained above, they were never a first choice from the perspective of those responsible for funding colonial regimes. The rapid expansion of international trade in the early 20th century provided opportunities to collect taxes more easily and cheaply, by taxing revenues from trade. Where international trade flourished, colonial authorities reduced their dependence on direct taxes, and sometimes abolished them entirely. Direct taxes remained more significant, and politically salient, in landlocked areas less affected by foreign trade, where per capita incomes were generally lower (Frankema and van Waijenburg 2014).

Head and hut taxes were, in the language I set out above, challenging but enforceable. The two other main sources of colonial state revenues, especially trade taxes and to some extent non-tax revenues, rather meet my definition of easy taxes. While conceptually distinct, both stemmed largely from the rapid growth in exports of products like palm oil, cocoa, sisal, cotton, groundnuts, coffee, rubber, and tobacco, and the food and manufactured imports that they financed. Africa was integrated into world trade in the 19th and 20th centuries principally as an exporter of primary commodities and an importer of manufactures. It was one of the most trade-oriented regions of the world. We do not have comprehensive and reliable figures for the period before 1960, but we know that Africa's share of world trade increased substantially in the 1920s and 1930s (Federico and Tena-Junguito 2019: 27). By the 1960s, the trade ratio (the ratio of imports and exports to GDP) for SSA was much higher than for any other poor world region (Table 1). Levying customs duties on imports and exports is historically the default method for large-scale political units to collect revenue. ${ }^{15}$

13 His operational definition of the concept covers Angola, Botswana, Kenya, Lesotho, Madagascar, Malawi, Mozambique, Namibia, South Africa, Swaziland, Zambia, and Zimbabwe.

$14 \quad$ Mkandawire demonstrated that this historical pattern showed up in comparisons between revenue-raising efforts in Africa over the period 1980-2004. Ligomeka (2019: chapter 6) shows that it persisted up to 2015.

15 It is generally easier to collect revenue at jurisdictional borders than, for example, to pursue and hassle small domestic traders or farmers-unless they operate well above the subsistence level and produce mainly for the market. Large 
Between 1900 and 1990, trade taxes accounted for between 30 and 40 per cent of total government revenue in the region (Albers et al. 2020: 5).

\section{Table 1 Average national trade ratio (ratio of imports and exports to GDP) for 3} regions, by decade, 1960-2019

\begin{tabular}{|c|c|c|c|c|c|c|}
\hline & 1960-69 & 1970-79 & 1980-89 & 1990-99 & 2000-09 & 2010-19 \\
\hline SSA & 43 & 48 & 43 & 46 & 60 & 56 \\
\hline South Asia & 13 & 14 & 18 & 25 & 38 & 45 \\
\hline Latin America \& Caribbean & 20 & 24 & 26 & 31 & 39 & 42 \\
\hline
\end{tabular}

Source: World Development Indicators.

In the colonial period, trade taxes were levied mainly on imports. International trade generated additional government revenue through another channel. SSA, particularly West Africa, has been notorious for public infrastructure spending driven primarily by the needs of the colonial commodity export economy. Economic activity was concentrated on a small number of large ports, most of them also territorial capitals, that were the terminal points of railway lines used to move agricultural commodity exports from the rural hinterland, without connecting to transport networks in neighbouring countries (Michalopoulos and Papaioannou 2020: 76-77). ${ }^{16}$ Colonial governments often owned the ports and railways, and, through the user charges they levied, benefited from significant 'non-tax revenues' (Albers et al. 2020; Frankema and Booth 2020).

In the 19th and 20th centuries, state fiscal authorities in Britain, aware of their ultimate answerability to a parliament dominated by large tax-paying interests, made great efforts to obtain taxpayer consent to new fiscal measures (Daunton 2001). British colonial administrators in Africa, like those of other colonial powers, operated under few such constrains in their taxing and spending. They rarely suffered much large-scale organized resistance from taxpayers. Indeed, there have been few cases of violent popular tax resistance in the region from that time until today. ${ }^{17}$ To some extent at least, ordinary Africans seem to have become socialized into perceiving themselves as duty-bearing taxpayers. Contemporary surveys suggest that today most perceive taxpaying to be a civic responsibility (Aiko and Logan 2014).

companies are in some ways attractive targets for the tax collector, but they often enjoy political influence and considerable bargaining power. They are generally not as vulnerable as transborder traders, who continually face the threat that, if they reject customs officers' assessments, their goods will be held at the border for days or weeks, if not impounded.

In recent decades the shift from railways to road transport, along with some road building, has provided long-distance traders with more choice over the ports in which to operate their import or export businesses-and thus scope to choose between the offers made for their businesses by competing customs posts. Competition can be within country or, especially in West Africa, among countries. 


\section{The historical trajectory: independence and after $^{18}$}

Colonial administrations generally had limited ambitions. Their principal functions were to keep order and allow the commodity export economy to thrive. Accordingly, they were not strongly motivated to raise large revenues. It was only very late in the colonial period that notions of investing public money to promote 'development' became at all widespread. Independent African governments had greater aspirations, and correspondingly experienced greater revenue needs (Herbst 2000; Young 1994). Their initial targets were the economic surpluses generated by agricultural commodity exports. Colonial regimes had mostly left these untouched, principally because taxing them would impair the profits of commoditytrading firms based in the colonial metropoles. ${ }^{19}$ In the 1960 s and early 1970 s, many African governments used both export taxes and administratively controlled foreign currency exchange rates to extract high-and sometimes ruinous - proportions of the incomes earned from agricultural commodity exports (Bates 1977; Bates 2008; Lipton 1977). These initiatives petered out after two decades or less. This was not generally because of major political resistance from cultivators, but rather because the revenue base wilted. High effective taxes, combined with a general decline in world market prices for Africa's commodity exports from the mid-1970s, made much agricultural commodity production unprofitable. Many farmers shifted to other crops, or to smuggling produce across borders to countries where export tax rates were less punishing. ${ }^{20}$

Independent governments also took more conventional measures to try to boost revenues, including the introduction of new and more modern taxes to broaden the collection base. Most introduced a broad sales tax in the 1960s or 1970s, generally in response to external advice and along the lines of the sales taxes that were well established in high-income countries. ${ }^{21}$ Through processes about which we have no consistent record, personal income tax (PIT) changed in character. In the colonial era, this term sometimes applied to the regressive direct head and hut taxes discussed above, levied mainly on people with low incomes. ${ }^{22}$ These were deeply unpopular, and gradually withered-or were taken over by local governments. Today, every country in SSA has a conventional PIT that is designed only to tax higher incomes. Typically, however, it does not achieve that aim. Very commonly, almost all PIT revenues come through the automatic deductions made from employees' salaries by government organizations and a few large private firms under the label of PayAs-You-Earn (PAYE). ${ }^{23}$ The fact that other PIT revenues are small indicates, as other

18 The main text does not deal with the impact of aid on revenue collection. For a period, SSA was quite aid-dependent. There is a plausible deductive argument that aid necessarily reduces the incentives for government to collect taxes from their own citizens and companies (Moyo 2009). The evidence suggests otherwise (Clist 2016; Morrissey et al. 2014).

19 Exceptions were the Gold Coast (Ghana), where taxes on cocoa exports were introduced before independence, and Uganda, where cotton exports were taxed soon after the establishment of colonial rule.

20 In the course of these tussles, the non-tax revenues that governments had earned from operating railways and ports shrank considerably (Albers et al. 2020: 5). Today, in most of SSA-as in most parts of the world except some largescale energy and mineral exporters-non-tax revenues account for only a few percentage points of total tax revenue.

21 I define a broad-based sales tax as one that qualifies for the label GST (General Sales Tax) in the Tax Introduction Database (TID, https://cadmus.eui.eu/handle/1814/65326). The TID identifies four countries in SSA in which GST was introduced during colonial rule, and another 34 in which it was introduced later. Among those 34 countries, 23 introduced GST in the 1960 s or 1970 s.

22 In the 48 countries for which there are data in the TID (see previous footnote), 33 had introduced PIT during colonial rule.

23 This information is available mostly where revenue collection statistics incorporate one figure for total income tax collection from individuals and another for total collections from PIT deductions made from pay cheques by employers (PAYE). The PAYE classification does not appear in the revenue statistics for francophone countries, but there are OECD data for five anglophone sub-Saharan African countries. In 2015, PAYE accounted for 97 per cent of total PIT collections in Kenya; 98 per cent of collections from taxes and profits of individuals in Rwanda; and 98 per cent and 96 per cent, on 
sources also tell us, that wealthy business people, highly paid professionals, and property owners are paying very little through the PIT mechanism (Section 7).

Trade taxes continued to be the largest single revenue source until the 1990s. The immediate reason for their relative decline thereafter was a set of national policy decisions to heavily cut rates of tax on imports and exports. But those decisions were shaped by changing material conditions. While the ratio of international trade to GDP continued to increase in SSA after 1960, the increase was small and unsteady (Table 1). ${ }^{24}$ Africa was not participating in the growth of global trade to anything like the degree of other low-income regions, and was to some extent being pushed to the margins of the global economy (Collier 2007). This lack of dynamism in the trade sector was one of the motivations for a package of tax reforms that included these reductions in trade taxes (mainly in import duties) and the introduction of the new VAT to replace the revenues lost. The tax reform package and the consequences of VAT are discussed in more detail in Section 5. For present purposes, it is useful to bear in mind that, with the introduction of VAT, revenues collected on imports declined far less than it would appear from the formal revenue accounts. Those accounts register big apparent shifts in revenue sources from 'trade taxes' to 'VAT'. But those are to some extent illusory. Probably around half of VAT revenues in the region are collected on imports, by the same customs officials who collect import duties, effectively through the same sets of assessment and collection procedures. ${ }^{25}$

This technical point about revenue classification relates to a larger issue. Trends and changes in tax collection levels in SSA today are still largely determined by international trade variables beyond the control of governments: the prices paid for imports and, even more, the fluctuating prices received for exports. It is important to understand the underlying sources of tax revenue, as opposed to formal classifications, and to bear those sources in mind when making either judgements about overall revenue collection performance or projections about future trends. We can illustrate the importance of global prices for export commodities using the Lund measure of total tax collections (Section 2). They suggest three main post-colonial 'revenue eras':

- Total revenues increased fairly fast from around 1960_approximately the peak of the decolonization process - until the mid-1970s. That was in part because world market prices for Africa's agricultural commodity exports were relatively buoyant at this time.

- There was then a period of around two decades, from the mid-1970s to the mid1990 s - after the efforts to extract revenue from commodity exports had largely fizzled out-when average national revenues almost plateaued. In this period, global prices for Africa's commodity exports were depressed, African governments became caught in major debt crises, its economies were performing poorly, and the outside

the same definition, in Swaziland and Uganda, respectively. In Ghana, 'employees' income tax' amounted to 93 per cent of PIT collections (OECD 2015: 178, 187, 193, 199, and 176).

24 Trade ratios have in recent decades increased much faster in most of the rest of the world. Today, the average trade ratio in SSA is not much above the ratios for South Asia and Latin America and the Caribbean (Table 1).

25 Many national tax authorities do not separate out import and domestic VAT in their revenue reports. The OECD provides figures for 2015 on eight mainland sub-Saharan African countries: Cameroon, Côte d'Ivoire, Democratic Republic of the Congo, Kenya, Niger, Togo, and Uganda. In these cases, import VAT ranged from 37 to 70 per cent of total VAT collections, and averaged 54 per cent (OECD 2015: 169-99). For 2019-20, the World Customs Organization provides data for 24 countries in mainland SSA on the proportion of revenue collected by customs that derives from 'general consumption taxes'. This is likely to refer almost exclusively to VAT. On average, these account for 49 per cent of total revenue being collected by customs (World Customs Organization 2020: 44-80). 
world began to believe that Africa was uniquely cursed by intractable governance problems. $^{26}$

- For the next two decades, from the mid-1990s until about 2012, average revenues again increased rapidly. This reflected both significant positive rates of economic growth in some parts of Africa and, again, high prices for commodity exports-but this time mainly prices of oil, gas, and minerals, rather than agricultural exports, which had greatly shrunk in value (Section 6).

Two issues mentioned above-the tax reform package and introduction of VAT, and the taxation of the new extractives export economy-are discussed in more detail in Sections 6 and 7 . They broadly represent the more positive and the more problematic aspects, respectively, of the ways in which national tax systems in SSA in recent decades have been adapted to the changing global context. Tax reform, especially the introduction of VAT, has opened up new revenue sources and to some extent improved the ways in which national tax administrations interact with taxpayers. By contrast, the new extractives sector, which represents a significant fraction of the regional economy, has to a large degree evaded the tax net. The contradictory effects of these two forces help to explain why the average revenue collection performance in the region in recent decades has been mediocre. The normal expectation is that sustained economic growth will lead to some increase in the ratio of tax collection to GDP. The sub-Saharan African regional economy has grown, but, over the period 1980-2017, the average ratio of national tax collection to GDP has not changed perceptibly (Gupta and Liu 2020).

\section{Revenue reform}

In most countries, tax reform seems to be a continuous process. At each annual budget, if not more often, ministers of finance announce changes in tax rates, in tax administrative processes, and often in tax law and in the structure of tax administration. While tax systems in SSA slowly evolved in this way for much of the 20th century, there was a significant change in pace in the 1990s. This resulted in part from widespread public sector debt crises in Africa in the 1980s, concern within African governments about the sustainability of their revenue bases, and the greater policy leverage available to the IMF, the World Bank, and aid donors after they stepped in to help deal with the debt crises. It also coincided with a leap in levels of democracy and political competition in Africa following the collapse of the Soviet Bloc and the end of the Cold War around 1990. Especially in the anglophone countries, tax reform became a more widespread and conscious process, with some measure of agreement on the goals. Not only were many African governments beset by problems of economic stagnation and debt, but their efforts since independence to seek new revenue sources had not been very successful. They were ready to accept advice that promised to remedy that. The IMF and a range of other international organizations and aid donors were willing to give it. The IMF in particular had an institutional responsibility to help indebted governments to raise more revenue so that they could reliably repay their (concessionary) loans and ultimately become creditworthy in the eyes of commercial lenders. There was perceptible African buy-in-most visibly from Uganda and Rwanda, where new reforming governments took over in 1986 and 1994, respectively, following periods of civil war and the near-collapse of state institutions. Albeit raggedly, and mostly without much public enthusiasm, African governments went along with the advice that there was a set of best practices in tax policy and administration, exemplified by those found in

26 It is likely that governance did deteriorate in the 1970s and 1980s, and that the decline in revenue collections in some countries was a significant cause (Bates 2008). 
rich countries, towards which they should move. That 'best practices' package, which had begun to emerge in the 1970s_mainly from within and around the IMF-encompassed two foundational principles:

- Revenue systems should be used to raise revenue efficiently. They should not typically be used for purposes of social engineering (e.g. redistributing income) or as tools for interventionist economic policies (e.g. promoting investment in particular industries), on the grounds that they are not effective for these purposes, and that the pursuit of competing goals tends to undermine the mission of efficient revenue collection.

- Tax administration is not secondary to tax policy; it largely is tax policy. Second-rate tax administration can easily undermine apparently first-rate tax policies. Improved tax administration should be a priority, with simplification as a key component: simple rules and principles; minimal tax exemptions; a narrow range of taxes; and few rate bands for any one tax. ${ }^{27}$

To these general principles, the IMF added a more substantive item. African governments should greatly reduce the tax rates they charged on imports and exports, in the interest of promoting international trade and economic specialization. In return, they were invitedsometimes quite insistently - to introduce the relatively new VAT, which had been initiated in France in 1964 and was steadily becoming global. It was mainly at the insistance of the World Bank and the British aid programme that another substantive item was added into the reform package: the removal of the tax administration function from the direct control of ministers of finance into new and putatively integrated semi-autonomous revenue authorities (henceforth SARAs).

The reform process has been extensively described and analysed elsewhere (Fossat and Bua 2013; Kloeden 2011; Moore 2014). For present purposes, the important points are:

- The most tangible and consequential change, the introduction of VAT, came early in the process. ${ }^{28}$

- There has been considerable progress in, among other things: changing organizational structures to reduce the amount of face-to-face contact between tax staff and taxpayers, and to shift the processes of assessment and collection toward more formal and impersonal channels; recruiting tax staff with higher educational and professional qualifications; increasing the proportion of female tax staff; and using digital and online technologies, especially for filing tax returns and making payments. On a range of measures of the quality of national tax administration, SSA now scores well relative to other lower-income world regions (Moore et al. 2018: 32-34).

- SARAs have been established in virtually every anglophone country and a few others. ${ }^{29}$ Although the evidence on their direct effect on revenue levels is ambiguous, ${ }^{30}$ this reform, along with the establishment of the African Tax

This approach to taxation has been labelled neo-liberal. That is valid to the extent that it represented a reaction against the previous tendency, globally and in Africa, to use taxation as an instrument for broad government activism and intervention. However, to the extent that the intention is to strengthen the state through better and more revenue collection, without significant privatization, the neo-liberal label is misplaced (Fjeldstad and Moore 2009).

28 Today, VAT is in place in 40 countries in SSA. In 30 of those cases, it was introduced between 1990 and 2004 , which was approximately the time of the initial wave of tax reforms. The figures are from the TID (https://cadmus.eui.eu/handle/1814/65326). By contrast, slightly fewer than half the SARAs currently in place were operational by 2004 (Dom 2019: table A.2).

29 Angola, Burundi, Mozambique, Rwanda, and Togo.

30 Roel Dom's (2019) very careful research on SSA indicates that the creation of SARAs has not generally resulted in greater increases in revenue collection compared with countries where they were not created. But SARA is a legal concept; the formal existence of a SARA does not necessarily indicate the degree of policy and managerial autonomy actually enjoyed by its senior executives. There is some recent evidence that, on a global basis, greater autonomy for the management of revenue administrations is associated with higher revenue collection (Chang et al. 2020). 
Administration Forum in 2009, fostered the emergence of something approaching a pan-African professional cadre of tax administration specialists with growing policy influence.

- VAT has emerged as the star of the show, albeit in controversial and rather puzzling ways. Publicly, it receives much more abuse than applause, and has always been criticized on the largely unjustified grounds that it is believed to have regressive effects on income distribution. ${ }^{31}$ Initially, too, the IMF was widely criticized for pressuring African tax administrations to adopt a tax that is administratively so complex. In essence, the burden of paying VAT falls on the final consumer of goods and services. But it is payable at each point in the production process where there is an economic transaction: when the logger sells her wood to the sawmill, and again when the sawmill sell planks to the furniture maker, the furniture maker sells tables to the furniture shop, and the furniture shop sells those tables to consumers.

Businesses registered for VAT need to keep accounts of all payments and receipts such that they actually pay the tax on the difference between their input costs and their receipts - their value-added. In principle, VAT embodies a partial self-enforcing mechanism. Each transaction creates a paper or electronic record, and at each point buyers and sellers have opposed incentives to under-value or over-value the transaction. That mechanism will, however, function only if tax administrations check records and sanction consistent defaulters, and thus give the message that the rules need to be obeyed. Such checking rarely takes place in SSA (Mascagni et al. 2021). Tax experts can provide an extensive list of faults in the design and administration of VAT in Africa. They include: an excessive and probably growing number of industry or product-specific exemptions that undermine VAT as an information source for tax administrators; and procedural problems and corruption in the payment of VAT refunds to exporters. There is a standard measure of the efficiency of VAT administration: actual collections as a proportion of potential collections. That figure is lower for SSA than for any other world region (Keen 2013). Despite all these problems, VAT remains-in SSA and elsewhere in the world-an excellent way for governments to raise revenue. Its primary strength lies in the fact that it mainly replaces sales taxes, which are principally levied on retailers, who can often and easily evade them. Being collectable at each point in the production chain, VAT is a more effective way of vacuuming in the cash. Tax administrations have become adept at deploying it. In SSA, VAT rates tend to be high, and VAT not only is the major single source of revenue by tax type, but also accounts for a higher proportion of government revenue here than in any other world region (Gendron and Bird 2020: 5). ${ }^{32}$

There is a widespread expert perception, backed by research evidence (Chang et al. 2020) that the kinds of tax reform that have been adopted in SSA, although in many respects products of global ideas and globally influential organizations, tend to work in poor countries. There is little evidence that the overall direction of reform has been mistaken. The challenges to raising more revenue in SSA lie in a series of more specific problems (Moore and Prichard 2017). In terms of magnitudes, both historically and for the foreseeable future, the biggest problem lies in governments' failure to capture a reasonable share of the surplus earned from the extraction of oil, gas, and minerals.

31 In essence, many of the goods consumed by poorer people are exempt from VAT, either by policy design (especially with regard to food) or because the enterprises that produce and retail the goods and services they consume are so small that they are not required to register for VAT (Alavuotunki and Pirttila 2015; Fischer et al. 2006).

32 As noted in Section 3, this is partly because of the high ratio of international trade to GDP and partly due to the fact that around half of VAT is collected on imports. It also reflects the fact that governments generally do not make enthusiastic use of income taxes. 


\section{Extractives problems}

The principal exports of most colonial territories in SSA were agricultural commodities. Large-scale mining has a long history in the region but was concentrated in South Africa, Northern

Rhodesia/Zambia, and the Congo (Congo/DRC). The balance between the two export sectors began to shift around 1970. Agricultural commodities went into relative decline (Section 4), and energy and mineral commodities blossomed. Nigeria and Gabon began to export oil in 1970 . They were joined in 1973 by the Republic of Congo (Congo) and in 1979 by Cameroon. In the next few decades, the global centre of gravity of extractives activities shifted somewhat from the Middle East and North Africa to SSA and Central Asia (Tables 2 and 3). Oil, gas, and minerals have become the dominant source of export earnings for SSA. For the five-year period 2014-18, fuel, minerals, and metals accounted for an average of 52 per cent of total exports by value, compared with only 15 per cent for animal, vegetable, and food products. ${ }^{33}$

\section{Table 2 Natural resource rents as a percentage of GDP by decade and source, SSA}

\begin{tabular}{|c|c|c|c|c|c|c|c|}
\hline Period & $\begin{array}{c}\text { Forest } \\
\text { rents }\end{array}$ & $\begin{array}{l}\text { Coal } \\
\text { rents }\end{array}$ & $\begin{array}{l}\text { Mineral } \\
\text { rents }\end{array}$ & $\begin{array}{l}\text { Natural } \\
\text { gas rents }\end{array}$ & $\begin{array}{c}\text { Oil } \\
\text { rents }\end{array}$ & $\begin{array}{l}\text { Total energy and } \\
\text { mineral rents } \\
{[(b) \text { to }(e)]}\end{array}$ & $\begin{array}{l}\text { Total natural } \\
\text { resources rents } \\
{[(a) \text { to }(e)]}\end{array}$ \\
\hline & (a) & (b) & (c) & (d) & (e) & (f) & (g) \\
\hline $1971-79$ & 2.5 & 0.9 & 1.6 & 0 & 4.5 & 7.0 & 9.5 \\
\hline 1980-89 & 2.5 & 1.2 & 1.8 & Negligible & 3.3 & 6.3 & 8.8 \\
\hline 1990-99 & 3.9 & 0.8 & 0.7 & Negligible & 3.5 & 5.0 & 8.9 \\
\hline 2000-09 & 3.0 & 0.9 & 1.0 & 0.2 & 7.3 & 9.4 & 12.4 \\
\hline 2010-18 & 2.7 & 0.6 & 2.2 & 0.5 & 6.0 & 9.3 & 12.0 \\
\hline
\end{tabular}

Source: World Development Indicators.

Table 3 Total natural resource rents as a percentage of GDP, by world region 19712018

\begin{tabular}{lrrrrr}
\hline & $\mathbf{1 9 7 1 - 7 9}$ & $\mathbf{1 9 8 0 - 8 9}$ & $\mathbf{1 9 9 0 - 9 9}$ & $\mathbf{2 0 0 0 - 0 9}$ & 2010-18 \\
Middle East \& North Africa & 35 & 22 & 17 & 26 & 23 \\
SSA & 9 & 9 & 9 & 12 & 12 \\
Russia, Caucasus \& Central Asia & n.a. & n.a. & 8 & 22 & 15 \\
Latin America \& Caribbean & 4 & 6 & 3 & 5 & 5 \\
North America & 3 & 3 & 1 & 1 & 1 \\
South Asia & 2 & 3 & 2 & 3 & 3 \\
East Asia \& Pacific & 2 & 3 & 1 & 2 & 2 \\
European Union & Negligible & Negligible & Negligible & Negligible & Negligible \\
World & 3 & 3 & 1 & 3 & 3 \\
\hline
\end{tabular}

Note: Figures cover rents from forestry, coal, oil, natural gas, and minerals, but exclude diamonds. They are weighted averages for each region.

Source: World Development Indicators.

This shift towards extractives is likely to continue. ${ }^{34}$ The revenue futures of an increasing number of sub-Saharan African countries therefore depend to a significant degree on the capacities of their governments to obtain a reasonable share of the rents-i.e. the surpluses over and above costs of production and normal profit-that typically result from the depletion

33 Data are from World Trade Indicators (https://wits.worldbank.org/wits/wits/witshelp/Content/Utilities/ e1.trade_indicators.htm).

34 The geology of Africa has been only lightly explored relative to much of the rest of the globe. However, exploration for new sub-soil resources tends to be especially successful there (Moore et al. 2018: 111), so the relative importance of the extractive sector may continue to increase, and more countries may join Mozambique and Uganda as new extractives exporters. Policies to reduce the extent of global warming are likely to result in increases in the prices of minerals and natural gas relative to oil. SSA and Central Asia are better endowed with mineral resources than is the MENA region. 
of natural capital, i.e. when oil, gas, minerals, and coal are dug up, and forests are cut down. Highly competent governments that serve the public interest should be able to use taxes and royalties to acquire nearly all those rents for the public treasury, leaving the operating companies, whether public or private, with enough of the surplus to cover costs and motivate investment. In reality, governments rarely manage to capture anything close to 100 per cent of the rents. In large part because the prospect of grabbing a share of them attracts an enormous amount of political activity (along with corruption and the use or threat of armed force), the public treasury always has to make do with less that the full amount of rent. However, among the governments that formally licence and oversee significant natural resource extraction activities, those in SSA (and in Central Asia) are much less successful than those of other regions, notably the Middle East and North Africa (MENA), in capturing a good share of natural resource rents (Tables 4 and 5). ${ }^{35}$

Table 4 Extent of government capture of natural resource rents, 2017-21

\begin{tabular}{lccc}
\hline $\begin{array}{l}\text { Region and number of } \\
\text { country observations }\end{array}$ & $\begin{array}{c}\text { (a) Average total natural } \\
\text { resource rents as \% of GDP }\end{array}$ & $\begin{array}{c}\text { (b) Average total natural resource } \\
\text { revenues as \% of GDP }\end{array}$ & (b)/(a) \\
SSA (18) & 21 & 10 & 0.49 \\
Central Asia (5) & 26 & 11 & 0.43 \\
MENA (6) & 35 & 33 & 0.73 \\
Other countries (16) & 13 & 10 & 0.76 \\
\hline
\end{tabular}

Note: Includes all countries where, for the period covered, total natural resource rents exceeded $5 \%$ of GDP. Figures are simple averages for countries in each region.

Source: World Development Indicators (column (a)); IMF (column (b)).

Table 5 Extent of government capture of natural resource rents, 2014-18

\begin{tabular}{lccc}
\hline $\begin{array}{l}\text { Region and number of } \\
\text { country observations }\end{array}$ & $\begin{array}{c}\text { (a) Average total natural } \\
\text { resource rents as \% of GDP }\end{array}$ & $\begin{array}{c}\text { (b) Average total natural resource } \\
\text { revenues as \% of GDP }\end{array}$ & (b)/(a) \\
SSA (19) & 18 & 6 & 0.53 \\
Central Asia (3) & 22 & 11 & 0.50 \\
MENA (6) & 27 & 24 & 0.88 \\
Other countries (9) & 15 & 9 & 0.62 \\
\hline
\end{tabular}

Note: Includes all countries where, for the period covered, total natural resource rents exceeded $5 \%$ of GDP. Figures are simple averages for countries in each region.

Source: World Development Indicators (column (a)); IMF (column (b)).

The reasons for this failure are complex and multi-layered. For Central Asia, part of the explanation is that the sector is new. It has grown enormously since the collapse of the Soviet Bloc, and governments are still learning how deal with that growth. But that explanation is less plausible for much of SSA, which has more experience with extractives. Ultimately, the explanation lies in inequalities in political and institutional power. For example, most oil-exporting governments in MENA have established some kind of national oil (and gas) parastatal corporation that directly controls production, and sometimes exploration, licensing, refining, transporting, and trading. By contrast, in SSA the extraction of oil, gas, and minerals is almost all in the hands of large private transnational corporations. But it is not just a matter of well intentioned but weak governments being outwitted by powerful transnationals. There is abundant evidence that the possibility of grabbing shares of natural resource rents has motivated levels of political competition and corruption that directly contribute to weakening states, including their efforts to get tax revenues from

The figures in Tables 4 and 5 derive from the only significant datasets I have been able to locate that quantify revenues from natural resources for large samples of countries over a recent period of several years. The IMF figures are likely the more accurate. Actual values for any one country will fluctuate from year to year in response to, among other things, changes in export commodity prices in global markets. 
natural resources. ${ }^{36}$ Not all natural resource rents that fail to end up in the public treasury go to transnational companies. Significant amounts are distributed through political channels of various kinds and end up in private pockets and in bank accounts and other assets abroad (Moore et al. 2018: chapter 5).

\section{Glimpses of fiscal states}

Political economists of various persuasions convincingly argue that long-term national political and economic development is significantly driven by synergies between higher revenue collection, improved public services, a more consensual and efficient style of tax administration, and a deeper engagement of citizens in peaceable political competition around fiscal policy (Besley and Persson 2013; Steinmo 2018). There is some statistical evidence that these synergies are at work in contemporary SSA. ${ }^{37}$ But they are not visible to the naked eye, and likely not very strong. Taxing practices seem focused on meeting revenue collection targets, as opposed to either improving the experience for taxpayers or trying to build up trust in government and in tax administrations. The substantial accomplishments in raising large amounts of money are not generally matched by a similar level of performance in broader revenue-related governance tasks: distributing the revenue tolerably fairly; protecting citizens against extortion in tax collection; achieving transparency; and encouraging and facilitating voluntary compliance on the part of taxpayers.

In the light of that general understanding of interactions between tax and governance, there seems to be some tension between the fact that sub-Saharan African states are relatively proficient tax collectors and the widespread perception that the region has not been very successful in constructing stable and legitimate political order. How can governments that are not generally high performers in terms of legitimacy and overall effectiveness score well in terms of revenue collection? There is in fact no great puzzle or contradiction. The conventional wisdom is couched at a high level of generalization. A few basic organizational features of tax collection explain how governments equipped only with the rudiments of a tax administration apparatus and some capacity to exercise coercion are able to earn sufficient revenue to keep themselves in business-albeit at the cost of abrasive relationships with taxpayers.

The organizational mission for 'basic taxation' could not be more clear: to reach or exceed annual collection targets. Those targets can be allocated precisely among sub-units and individual staff members, and between months or quarters. Performance can be continuously and closely monitored. Staff should not generally lack job motivation, since a significant fraction of their formal remuneration is tied to achieving collection targets, and the opportunity to supplement earnings informally helps to ensure that the job is materially attractive and worth retaining. Should staff under-perform, replacement is not difficult. High levels of professional training or competence are not required. This brutally simple organizational model enabled early African colonial administrations to extract significant revenues from distinctly 'dry' (or 'non-juicy') sources. Proficient tax administrations were constructed principally on the bases of this muscular approach to collection and access to relatively large, easy-to-tax international trade sectors (Section 3 ). Recent reforms have relaxed some of the muscularity and extended the capacity to tax internal economic transactions (Section 5).

\footnotetext{
36 There is a very large literature on this, under the rubric of the 'resource curse'.
}

37 I refer to ongoing research by Abrams Tagem and Oliver Morrissey. 
For the last two decades or more, most African states have qualified as tax states in the original Schumpeterian sense of the term (Introduction): they finance themselves mainly from broad general taxation, and not principally from the earnings of state-owned assets like land, industry, mines, post offices, and railways, or from state trading monopolies in products like salt or alcohol. ${ }^{38}$ Before the impact of Covid, a few were becoming fiscal states. They had established sufficiently reliable tax bases-and thus debt repayment capacities-to be able to borrow at commercial rates on international financial markets (Introduction). However, even before the (still uncertain) impact of Covid on African economies, revenues, and public policies, the prospects of increasing government revenue collections faster than rates of increase in GDP were uncertain (Introduction). Genuine statistical ignorance and uncertainty are at play. GDP figures are not very reliable. The revenues obtained from the extractives sector-often large even if well below the theoretical potential-are poorly accounted for, and they vary considerably in response to fluctuations in international commodity prices. We are still unable, for the region as a whole, accurately to track revenue trends separately for the extractive and the non-extractive sectors. We do not know how well tax administrations are doing in capturing additional income generated outside the extractive sector. But it is reasonable to assume rocky paths towards both (a) increasing revenue collections relative to GDP and (b) constructing more taxpayer-friendly collection systems. I conclude by summarizing five significant problem areas.

First, African tax administrations are unable adequately to tax transnational corporations and transactions. This is especially true in relation to renewable natural resource extraction (Section 5), but the basic dynamics are similar in tobacco and alcohol, where small numbers of large TNCs lobby effectively against sensible levels of excise taxes (Savedoff and Alwang 2015), and newer expanding economic sectors like telecommunications and transactions in digital services (and by digital means). In these latter sectors, dearth of technical knowledge and capacity within tax administrations is clearly an important part of the story. That seems less significant in relation to natural resource extraction or tobacco and alcohol. There is an abundance of good technical advice on how best to tax natural resource extraction. A more immediate cause of poor performance is political competition of all kinds, mostly involving illegality and corruption, to grab shares of the very large natural resource rents. It is, however, always difficult to allocate responsibility for taxation failures between 'politics' on the one side and 'administrative incapacity' on the other. The organizational incapacity of any tax administration may be the result of policy decisions to protect particular interests against taxation, in deniable ways, by tying the hands of the tax collector. Tax administrations may be rendered incompetent through, among other things, limitations on their budgets or investigatory powers, omissions or bad drafting in legislation, or the choice of senior staff.

Second, African tax administrations tend not to use their muscle very actively against richer Africans. This is not a new problem. The UN pointed it out in the 1970s, when there were far fewer wealthy Africans than today (Herbst 2000: 119). There is some evidence that the cause lies more in politics than in capacity constraints within tax administrations. The immediate reason that many modestly wealthy Africans pay little or no personal income tax is not that they hide their incomes and assets in offshore bank accounts and trusts that are hard to track down; it is rather that tax administrations make little effort even to ensure that they complete an annual personal tax return (Kangave et al. 2016; Kangave et al. 2018; Kangave et al. 2020). In a similar way, governments make limited efforts to update property 
registers and property tax systems in cities where real estate investments and prices are booming. ${ }^{39}$

Third, tax systems tightly focused on meeting aggregate collection targets tend to generate more problems and collateral damage as they pan out from their core territory of taxing the movement of goods through ports and the sales and profits of larger businesses. The costs are borne mainly by small and very small businesses. They are relatively powerless in their dealings with field-level tax staff, whose senior national tax administrators exercise little supervisory oversight, in part because those administrators are focused on the small number of larger companies that, in most African countries, provide a high proportion of the revenues collected. Further, harassment of smaller businesses is to some extent embedded in organizational policies and procedures. Recent research reveals the extent to which even the more competent African tax administrations require small-scale enterprises to follow complex and obscure procedures in filing their tax returns (Mascagni et al. 2020), and to register as taxpayers even when the chances that they should or will actually pay tax are very small (Moore 2020).

Fourth, the ways in which small businesses are treated in part reflects the fact that African national tax administrations tend to be responsible for taxing both (a) large-scale business and (b) the very small enterprises that in other circumstances would be clients of the revenue collectors working for sub-national governments (Moore 2020). Most states in SSA are fiscally highly centralized, to the extent that there is little reliable public information on either the revenues or the expenditures of local government. National and sub-national fiscal systems sometimes barely mesh at all; national authorities may simply not know what revenues sub-national governments are collecting, or how they are using them. The main cause of this dualism lies deep in history. When in the late 19th and early 20th centuries European colonial authorities fully extended their rule over the African territories they had allocated to themselves at inter-governmental meetings in Berlin, they had very low budgets, and were often interested in doing little more than basic revenue collection, for which they used locally influential intermediaries (Section 3). Those intermediaries, typically labelled 'traditional chiefs', often remain influential today (Logan 2009; Mamdani 1996). In much of Africa, local government is not very formalized or institutionalized. ${ }^{40} \mathrm{It}$ is for this reason in practice difficult to distinguish between the realm of formal local government taxation and the realm of non-state revenue raising, populated by community groups, traditional chiefs, religious organizations, vigilantes, and armed militias. It is likely that more people in SSA pay taxes at the local level to these kinds of agents than to official national tax collectors. The degree of coercion exercised in local-level collection varies widely. All the evidence suggests that the amounts collected are significant as a proportion of the incomes of the taxpayers, and that the burden is almost always distributed regressively (Van den Boogaard and Prichard 2016).

Finally, the standard approach to tax reform that in recent decades has been relatively successful in the region-and especially in the anglophone countries-is not appropriate to the swathe of states across the centre of Africa currently affected by political instability, armed conflict, and cross-border insurgencies. The standard approach emphasizes the cultivation of quasi-voluntary compliance over muscular enforcement, the integration of different taxing functions and organizations, and the shifting of the tax burden from international trade to internal economic transactions. It assumes relatively centralized polities

Also, because power in SSA tends still to inhere in the state apparatus itself and the people who staff it, government organizations widely default on their obligations to pay tax or provide tax-related information to the tax administration (Saka et al. 2018)

40 The tax reform processes discussed in Section 5 focused almost entirely-and probably unavoidably-on national-level organizations and thus exacerbated this divide between national and sub-national taxation. 
that directly exercise some control over most of their territories and populations. Those conditions are not met in significant parts of the Sahel (Senegal, Mauritania, Mali, Burkina Faso, Niger, Northern Nigeria, Cameroon, Central African Republic, Chad, Sudan, South Sudan) or in Somalia. Revenue raising in those states continues to depend relatively heavily on customs posts at land frontiers. ${ }^{41}$ Customs posts are often the only significant nodes of state authority over large areas, and sometimes provide funding directly to other state agencies in their localities. Most of the countries in question are francophone. None of them adopted the (anglophone) fashion of merging customs with internal revenue departments within semi-autonomous revenue authorities. ${ }^{42}$ The increasing emphasis of customs responsibilities on border security means that integration is now totally off the policy agenda. Francophone customs organizations are by tradition semi-militarized: their staff may receive military training, wear full uniform while on duty, and are often armed. Similarly, Sudan's Customs Authority has always been responsible to the Ministry of the Interior rather than the Ministry of Finance. The Nigeria Customs Service has an armed Customs Police Unit, and staff have recently received firearms training from the army. Thomas Cantens and Gael Rabelland (2021) argue persuasively that expanding the capacities and remit of customs administrations may be an essential step in the establishment of legitimate political authority and peace in Africa's conflict-affected regions. Other revenue sources cannot easily be tapped during conflict. ${ }^{43}$ Cantens and Rabelland further suggest that reform based around the monitoring and data-analysis capacities of digital technologies could contribute significantly to reducing the misuse of customs revenues and establishing a greater degree of state control. Their analysis constitutes a substantial challenge to the standard reform model, and suggests that we need to think more explicitly about the existence of more than one high road towards the construction of fiscal states in SSA.

Customs still collect a large proportion of total government revenues in most countries in SSA, in part because, as explained in Section 4, they collect around half of all VAT. The World Customs Organization reports on the proportion of total tax revenue collected by customs for 24 countries in mainland SSA for the year 2019-20. On average, customs collected 33 per cent of the total. The figures were, however, generally exceptionally low in Southern Africa. If we exclude Botswana, Eswatini, Lesotho, Mozambique, Namibia, and South Africa, the average is 40 per cent. Political instability typically translates directly into missing revenue statistics. In this case, data are available for only one of the twelve conflict-affected countries mentioned in the main text (World Customs Organization 2020: 44-80). 


\section{References}

African Development Bank (2021). African Economic Outlook 2021. Abidjan: African Development Bank.

Aiko, R., and C. Logan (2014). 'Africa's willing taxpayers thwarted by opaque tax systems and corruption'. Afrobarometer Policy Paper 7.

Akitoby, B., J. Honda, and K. Primus (2020). 'Tax revenues in fragile and conflict-affected states - why are they low and how can we raise them?'. Working Paper 20/143. Washington, DC: IMF. https://doi.org/10.5089/9781513550848.001

Alavuotunki, K., and J. Pirttila (2015). 'The consequences of the value-added tax on inequality'. WIDER Working Paper 20/143. Helsinki: UNU-WIDER. https://doi.org/10.35188/UNU-WIDER/ 2015/000-3

Albers, T., M. Jerven, and M. Suesse (2020). 'The fiscal state in Africa: evidence from a century of growth'. Working Paper 55/2020. Lund: African Economic History Network.

Bates, R. (1977). Markets and states in tropical Africa. The political basis of agricultural policies. Berkeley: University of California Press.

Bates, R.H. (2008). When things fell apart. State failure in late-century Africa. Cambridge and New York: Cambridge University Press. https://doi.org/10.1017/CBO9780511790713

Bayart, J.-F. (1993). The state in Africa. The politics of the belly. London: Longman.

Bayart, J.-F., S. Ellis, and B. Hibou (1999). The criminalization of the state in Africa. Oxford: James Currey.

Besley, T., and T. Persson (2013). 'Taxation and development'. In A. Auerbach, R. Chetty, M. Feldstein, and E. Saez (eds), Handbook of public economics, Volume 5. London: Elsevier. https://doi.org/10.1016/ B978-0-444-53759-1.00002-9

Cantens, T., and G. Rabelland (2021). 'Taxation and customs reforms in fragile states: between bargaining and enforcement'. Working Paper 120. Brighton: International Centre for Tax and Development. https://doi.org/10.19088/ICTD.2021.009

Chabal, P., and J.P. Daloz (1999). 'Africa works: disorder as political instrument'. Oxford and Bloomington, IND: James Currey and Indiana University Press.

Chang, E.S., E. Gavin, N. Gueorguiev, and J. Honda (2020). 'Raising tax revenue: how to get more from tax administrations'. Working Paper 20/142. Washington, DC: IMF. https://doi.org/10.5089/ 9781513550831.001

Clist, P. (2016). 'Foreign aid and domestic taxation: multiple sources, one conclusion'. Development Policy Review, 34(3): 365-83. https://doi.org/10.1111/dpr.12154 
Collier, P. (2007). The bottom billion. Why the poorest countries are failing and what can be done about it. Oxford: Oxford University Press.

Daunton, M. (2001). Trusting Leviathan. The politics of taxation in Britain 1799-1914. Cambridge: Cambridge University Press.

Dom, R. (2019). 'Semi-autonomous revenue authorities in sub-Saharan Africa: silver bullet or white elephant'. Journal of Development Studies, 55(7): 1418-35.

https://doi.org/10.1080/

00220388.2018 .1469743

Englebert, P. (2000). State legitimacy and development in Africa. Boulder, CO: Lynne Rienner.

Federico, G., and A. Tena-Junguito (2019). 'World trade, 1800-1938: a new synthesis'. Journal of Iberian and Latin American Economic History, 37(1): 9-41. https://doi.org/10.1017/S0212610918000216

Fischer, R., P. Gonzalez, and P. Serra (2006). 'Does competition in privatized social services work? The Chilean experience'. World Development, 34(4): 647-64. https://doi.org/10.1016/ j.worlddev.2005.09.008

Fjeldstad, O.-H., and M. Moore (2009). 'Revenue authorities and public authority in subSaharan Africa'. Journal of Modern African Studies, 47(1): 1-18. https://doi.org/10.1017/S0022278X08003637

Fossat, P., and M. Bua (2013). 'Tax administration reform in the Francophone countries of sub-Saharan Africa'. Working Paper 13/173. Washington, DC: IMF. https://doi.org/10.5089/9781475581539.001

Frankema, E., and A. Booth (eds) (2020). Fiscal capacity and the colonial state. Cambridge and New York: Cambridge University Press.

Frankema, E., and M. van Waijenburg (2014). 'Metropolitan blueprints of colonial taxation? Lessons from fiscal capacity building in British and French Africa c. 1880-1940'. Journal of African History, 55(3): 371-400. https://doi.org/10.1017/S002185371400036X

Gendron, P.-P., and R.M. Bird (2020). 'VAT gaps in developing countries: measurement, administration and politics'. Available at SSRN: https://doi.org/10.2139/ssrn.3696578

Gupta, S., and J. Liu (2020). 'Can tax buoyancy in sub-Saharan Africa help finance the sustainable development goals?'. Working Paper 532. Washington, DC: Center for Global Development.

Herbst, J. (2000). States and power in Africa. Comparative lessons in authority and control. Princeton, NJ: Princeton University Press.

Hopkins, A.G. (2009). 'The new economic history of Africa'. Journal of African History, 50(2): 155-77. https://doi.org/10.1017/S0021853709990041 
Jerven, M. (2013). Poor numbers: how we are misled by African development statistics and what to do about it. Ithaca, NY: Cornell University Press. https://doi.org/10.5771/05067286-2013-3-336

Kangave, J., S. Nakoto, R. Waiswa, and P. Zzimbe (2016). 'Boosting revenue collection through taxing high net worth individuals: the case of Uganda'. Working Paper 45. Brighton: International Centre for Tax and Development. https://doi.org/10.2139/ssrn.2776590

Kangave, J., S. Nakoto, R. Waiswa, M. Nalukwago, and P. Zzimbe (2018). 'What can we learn from the Uganda Revenue Authority's approach to taxing high net worth individuals?'. Working Paper 72. Brighton: International Centre for Tax and Development. https://doi.org/10.2139/ssrn.3120579

Kangave, J., K. Byrne, and J. Karangwa (2020). 'Tax compliance of wealthy individuals in Rwanda'. Working Paper 109. Brighton: International Centre for Tax and Development.

Keen, M. (2013). 'The anatomy of the VAT'. Working Paper 13/111. Washington, DC: IMF. https://doi.org/10.5089/9781484330586.001

Keen, M., and J. Slemrod (2021). Rebellion, rascals and revenue. Tax follies and wisdom through the ages. Princeton, NJ: Princeton University Press. https://doi.org/10.1515/9780691199986

Kloeden, D. (2011). 'Revenue administration reforms in anglophone Africa since the early 1990s'. Working Paper 11/162. Washington, DC: IMF. https://doi.org/10.5089/9781455296736.001

Lieberman, E.S. (2003). Race and regionalism in the politics of taxation in Brazil and South Africa. New York and Cambridge: Cambridge University Press. https://doi.org/10.1017/CBO9780511615658

Ligomeka, W. (2019). 'Tax revenue mobilisation in Malawi'. PhD, Development Studies, University of Sussex.

Lipton, M. (1977). Why poor people stay poor. urban bias in world development. London: Temple Smith. https://doi.org/10.5771/0506-7286-1978-4-462

Logan, C. (2009). 'Selected chiefs, elected councillors and hybrid democrats: popular perspectives on the co-existence of democracy and traditional authority'. Journal of Modern African Studies, 47(1): 101-28. https://doi.org/10.1017/S0022278X08003674

Long, C., and M. Miller (2017). 'Taxation and the sustainable development goals. Do good things come to those who tax more?'. Briefing Note. London: Overseas Development Institute.

Mamdani, M. (1996). Citizen and subject. Contemporary Africa and the legacy of late colonialism. Princeton, NJ: Princeton University Press.

Mascagni, G., F. Santoro, D. Mukama, J. Karangwa, and N. Hazimana (2020). 'Active ghosts: nil filing in Rwanda'. Working Paper 106. Brighton: International Centre for Tax and Development. 
Mascagni, G., R. Dom, and F. Santoro (2021). 'The VAT in practice: equity, enforcement and complexity'. Working Paper 117. Brighton: International Centre for Tax and Development. https://doi.org/ 10.19088/ICTD.2021.002

Michalopoulos, S., and E. Papaioannou (2020). 'Historical legacies and African development'. Journal of Economic Literature, 58(1): 53-128. https://doi.org/10.1257/jel.20181447

Mkandawire, T. (2010). 'On tax efforts and colonial heritage in Africa'. Journal of Development Studies, 46(10): 1647-69. https://doi.org/10.1080/00220388.2010.500660

Moore, M. (2014). 'Revenue reform and statebuilding in anglophone Africa'. World Development, 60(8): 99-112. https://doi.org/10.1016/j.worlddev.2014.03.020

Moore, M. (2020). 'What is wrong with African tax administration?'. Working Paper 111. Brighton: International Centre for Tax and Development.

Moore, M., and W. Prichard (2017). 'How can governments of low-income countries collect more tax revenue?'. Working Paper 70. Brighton: International Centre for Tax and Development. https://doi.org/10.2139/ssrn.3120566

Moore, M., P. Wilson, and O.-H. Fjeldstad (2018). Taxing Africa. Coercion, reform and development. London: Zed Press. https://doi.org/10.5040/9781350222861

Morrissey, O., W. Prichard, and S. Torrance (2014). 'Aid and taxation: exploring the relationship using new data'. Working Paper 21. Brighton: International Centre for Tax and Development. https://doi.org/10.2139/ssrn.2496453

Moyo, D. (2009). Dead aid: why aid is not working and how there is another way for Africa. London: Allen Lane.

OECD (2015). 'African revenue statistics 1990-2015'. Paris: OECD.

Prichard, W. (2016). 'Reassessing tax and development research: a new dataset, new findings, and lessons for research'. World Development, 80: 48-60.

https://doi.org/10.1016/j.worlddev.2015.11.017

Saka, H., R. Waiswa, and J. Kangave (2018). 'Taxing government: the case of the Uganda Revenue Authority's Public Sector Office'. Working Paper 84. Brighton: International Centre for Tax and Development.

Savedoff, W., and A. Alwang (2015). 'The single best health policy in the world: tobacco taxes'. Policy Paper 62. Washington, DC: Center for Global Development.

Schumpeter, J.A. (1918/1991). 'The crisis of the tax state'. In R.A. Swedberg (ed.), Joseph A. Schumpeter. The economics and sociology of capitalism, pp. 99-140. Princeton, $\mathrm{NJ}$ : Princeton University Press.

Steinmo, S. (ed.) (2018). The leap of faith. The fiscal foundations of successful government in Europe and America. Oxford and New York: Oxford University Press. https://doi.org/10.1093/oso/ 9780198796817.001 .0001 
Van den Boogaard, V., and W. Prichard (2016). 'What have we learned about informal taxation in sub-Saharan Africa?'. Summary Brief 2. Brighton: International Centre for Tax and Development.

World Customs Organization (2020). Annual Report. Brussels: World Customs Organization. https://doi.org/10.30875/4a0b4159-en

Young, C. (1994). The African colonial state in comparative perspective. New Haven and London: Yale University Press.

Yun Casalilla, B., and P.K. O'Brien (eds) (2012). The rise of fiscal states: a global history, 1500-1914. New York: Cambridge University Press.

https://doi.org/10.1017/CBO9781139004237 